\title{
Antioxidant properties and enzyme inhibitory effects of extracts from Mandragora autumnalis and its fatty acid composition
}

Sengul UYSAL, Gokhan ZENGİN, Abdurrahman AKTUMSEK

\begin{abstract}
The present research was performed to evaluate antioxidant activities and enzyme inhibitory potentials of two extracts (acetone and methanol) from two parts (flowers and leaves) of Mandragora autumnalis. The antioxidant properties were evaluated by using different methods. Enzyme inhibitory potentials were tested against cholinesterase (AChE and BChE), tyrosinase, $\alpha$-amylase and $\alpha$-glucosidase. Fatty acids, total phenolics and flavonoid content were investigated for phytochemical composition. Generally, the methanolic extract
\end{abstract}

of flowers (F-Met) exhibited the strongest antioxidant effect with the highest level of phenolics. Total phenolic and flavonoid content were determined as 26.10-46.92 mgGAE/g extract and 3.60-26.11 mgRE/g extract, respectively. $\alpha$ - linolenic acid was found to be major fatty acids in the studied oils $(33.81 \%$ for flowers and $39.15 \%$ for leaves). The study suggested that $M$. autumnalis could be valuable as a source of natural agents in food and pharmaceutical applications.

Keywords: antioxidant activity, enzyme inhibitory activity, Mandragora autumnalis, phenolic compounds.
Sengul UYSAL, Gokhan ZENGİN, Abdurrahman AKTUMSEK

Department of Biology, Science Faculty, Selcuk University, Konya, Turkey

Corresponding author: Sengul UYSAL

Tel.: +903322232781 Fax: +903322410106

E-mail: sennguluysal@gmail.com

Submitted/Gönderilme: 27.01.2016 Accepted/Kabul: 31.03.2016
Revised/Düzeltme: 29.03.2016

\section{INTRODUCTION}

Plants have great attention as not only food but also sources of drugs since long ancient times. In recent decades, plant or plant products are thinking as major sources of preparing new drugs or functional preparations due to the fact that synthetic compounds possess unfavorable side effects against human health. Thus, new researches on plants or theirs biological activities are very popular subject in scientific area (1). At this point, uninvestigated wild plants could be considered as a valuable pool for designing new functional products.

Mandragora L. (Solaneceae) commonly known as Mandrake. Mandragora genus is represented by 2 species in Turkey namely, $M$. autumnalis and $M$. officinarum (2). Mandragora autumnalis known by several local names such as at elmasi, yer yenidünyası ( Silifke, Mersin) and köpek elması, insan otu, kan kurutan (Kalkan, Kinık, Antalya) in Turkey (3). Mandrake dates back thousands of years and it was used for surgical anesthesia for 15 centuries $(4,5)$. In addition, 
different parts (root, fruit, and leaves) of Mandragora species were used as treatment for many diseases [including pain, insomnia, eye diseases, inflammation and ulcers] in ancient time (6). Several studies were shown the phytochemical profile (alkaloids, essential oils, etc.) of Mandragora species including $M$. autumnalis $(7,8,9,10)$.

In the last few decades, the number of people with diabetes and Alzheimer's has been greatly increased. For instance, International Diabetes Federation (IDF) estimated that diabetes affected about 415 million people worldwide in 2015 and it will increased to 642 million by $2040(11,12)$. In this context, the exploration of new treatment strategies for these global health problems is one of the most important subjects in medicinal and pharmaceutical areas. Among these strategies, key enzyme inhibition theory is accepted as the most valuable approach. From this point, many synthetic enzyme inhibitors are produced but they have several side effects such as gastrointestinal disturbances and hepatotoxicity (13, 14). Therefore, leads international efforts have targeted to find enzyme inhibitors [cholinesterase enzyme inhibitors for Alzheimer's disease, tyrosinase inhibitors for skin diseases, $a$-amylase and $\alpha$-glucosidase enzyme inhibitors for diabetes] from natural resources.

With these bases, the objectives of this study were to (i) determine the antioxidant properties of two extracts (acetone and methanol) of two parts (flowers and leaves) of M. autumnalis, (ii) evaluate enzyme inhibitory potentials of these extracts against cholinesterase, tyrosinase, amylase and glucosidase, and (iii) identify fatty acid compositions of these parts.

\section{MATERIALS AND METHODS}

\section{Plant Materials}

The flowers and leaves of Mandragora autumnalis were collected from Mersin-Silifke, Turkey and was identified by Dr. Murad Aydin SANDA. The voucher specimen was deposited in the herbarium of Department of Biology, Selcuk University (KNYA); herbarium code number: GZ 1451.

\section{Preparation of the extracts}

Aerial plant materials were dried at the room temperature. The dried plant materials were ground to a fine powder using a laboratory mill. Powdered $M$. autumnalis flowers and leaves [15 g] were extracted with $250 \mathrm{~mL}$ of solvent acetone, methanol using the by Soxhlet apparatus for 6-8 h. Extracts (flowers acetone (F-Ac), flowers methanol (F-Met), leaves acetone (L-Ac) and leaves methanol (L-Met)) were then filtered and concentrated under vacuum at $40{ }^{\circ} \mathrm{C}$ by using a rotary evaporator. Extracts were kept at $+4^{\circ} \mathrm{C}$ in dark until analysis.

\section{Total phenolic content}

The total phenolic content was determined by employing the methods given in the literature (15) with slight modification. Sample solution $(0.25 \mathrm{~mL})$ was mixed with diluted FolinCiocalteu reagent $(1 \mathrm{~mL}, 1: 9)$ and shaken vigorously. After $3 \mathrm{~min}, \mathrm{Na}_{2} \mathrm{CO}_{3}$ solution $(0.75 \mathrm{~mL}, 1 \%)$ was added and the sample absorbance was read at $760 \mathrm{~nm}$ after a $2 \mathrm{~h}$ incubation at room temperature. The total phenolic content was expressed as equivalents of gallic acid.

\section{Total flavonoid content}

The total flavonoid content was determined using the Dowd method (16). Briefly, sample solution (1 mL) was mixed with the same volume of aluminium trichloride (2\%) in methanol. Similarly, a blank was prepared by adding sample solution $(1 \mathrm{~mL})$ to methanol $(1 \mathrm{~mL})$ without $\mathrm{AlCl}_{3}$. The sample and blank absorbances were read at $415 \mathrm{~nm}$ after a $10 \mathrm{~min}$ incubation at room temperature. The absorbance of the blank was subtracted from that of the sample. The total flavonoid content was expressed as equivalents of rutin

\section{Free radical scavenging activity (DPPH assay)}

The effect of the samples on 1,1-diphenyl-2-picrylhydrazyl (DPPH) radical was estimated according to Sarikurkcu (17). Sample solution $(1 \mathrm{~mL})$ was added to a $4 \mathrm{ml}$ of a $0.004 \%$ methanol solution of DPPH. The sample absorbance was read at $517 \mathrm{~nm}$ after a $30 \mathrm{~min}$ incubation at room temperature in dark. The free radical scavenging activity was expressed as equivalents of trolox.

\section{Phosphomolybdenum method}

The total antioxidant activity of the samples was evaluated by phosphomolybdenum method according to Berk et al. (18) with slight modification. Sample solution $(0.3 \mathrm{~mL})$ was combined with $3 \mathrm{~mL}$ of reagent solution (0.6 M sulfuric acid, $28 \mathrm{mM}$ sodium phosphate and $4 \mathrm{mM}$ ammonium molybdate). The sample absorbance was read at $695 \mathrm{~nm}$ after a 90 min incubation at $95^{\circ} \mathrm{C}$. The total antioxidant capacity was expressed as equivalents of trolox.

\section{Cupric ion reducing (CUPRAC) method}

The cupric ion reducing activity (CUPRAC) was determined according to the method of Apak et al (19). Sample solution $(0.5 \mathrm{~mL})$ was added to premixed reaction mixture containing $\mathrm{CuCl}_{2}(1 \mathrm{~mL}, 10 \mathrm{mM})$, neocuproine $(1 \mathrm{~mL}, 7.5 \mathrm{mM})$ and $\mathrm{NH}_{4}$ Ac buffer (1 mL, $1 \mathrm{M}, \mathrm{pH}$ 7.0). Similarly, a blank was prepared by adding sample solution $(0.5 \mathrm{~mL})$ to premixed reaction mixture $(3 \mathrm{~mL})$ without $\mathrm{CuCl}_{2}$. Then, the sample and blank absorbances were read at $450 \mathrm{~nm}$ after a $30 \mathrm{~min}$ 
incubation at room temperature. The absorbance of the blank was subtracted from that of the sample. CUPRAC activity was expressed as equivalents of trolox.

\section{Ferric reducing antioxidant power (FRAP) method}

The FRAP assay was carried out as described by Aktumsek et al. (20) with slight modification. Sample solution $(0.1 \mathrm{~mL})$ was added to premixed FRAP reagent $(2 \mathrm{~mL})$ containing acetate buffer (0.3 M, pH 3.6), 2,4,6-tris(2-pyridyl)-s-triazine (TPTZ) $(10 \mathrm{mM})$ in $40 \mathrm{mM} \mathrm{HCl}$ and ferric chloride $(20 \mathrm{mM})$ in a ratio of 10:1:1 ( $\mathrm{v} / \mathrm{v} / \mathrm{v})$. Then, the sample absorbance was read at $593 \mathrm{~nm}$ after a $30 \mathrm{~min}$ incubation at room temperature. FRAP activity was expressed as equivalents of trolox.

\section{Metal chelating activity on ferrous ions}

The metal chelating activity on ferrous ions was determined by the method described by Zengin and Aktumsek (21). Briefly, sample solution $(2 \mathrm{~mL})$ was added to $\mathrm{FeCl}_{2}$ solution $(0.05 \mathrm{~mL}, 2 \mathrm{mM})$. The reaction was initiated by the addition of $5 \mathrm{mM}$ ferrozine $(0.2 \mathrm{~mL})$. Similarly, a blank was prepared by adding sample solution $(2 \mathrm{~mL})$ to $\mathrm{FeCl}_{2}$ solution $(0.05$ $\mathrm{mL}, 2 \mathrm{mM})$ and water $(0.2 \mathrm{~mL})$ without ferrozine. Then, the sample and blank absorbances were read at $562 \mathrm{~nm}$ after 10 min incubation at room temperature. The absorbance of the blank was subtracted from that of the sample. The metal chelating activity was expressed as equivalents of EDTA.

\section{Enzyme inhibitory activity}

\section{Cholinesterase inhibition}

Cholinesterase (ChE) inhibitory activity was measured using Ellman's method, as previously reported (22) with slight modification. Sample solution $(50 \mu \mathrm{L})$ was mixed with DTNB $(125 \mu \mathrm{L})$ and $\mathrm{AChE}$ (or BChE) solution $(25 \mu \mathrm{L})$ in Tris- $\mathrm{HCl}$ buffer ( $\mathrm{pH} 8.0$ ) in a 96-well microplate and incubated for 15 $\min$ at $25^{\circ} \mathrm{C}$. The reaction was then initiated with the addition of acetylthiocholine iodide (ATCI) or butyrylthiocholine chloride (BTCl) $(25 \mu \mathrm{L})$. Similarly, a blank was prepared by adding sample solution to all reaction reagents without enzyme (AChE or BChE) solution. The sample and blank absorbances were read at $405 \mathrm{~nm}$ after a 10 min incubation at $25^{\circ} \mathrm{C}$. The absorbance of the blank was subtracted from that of the sample and the cholinesterase inhibitory activity was expressed as equivalents of galanthamine.

\section{Tyrosinase inhibition}

Tyrosinase inhibitory activity was measured using the modified dopachrome method with L-DOPA as substrate, as previously reported (23) with slight modification. Sample solution $(25 \mu \mathrm{L})$ was mixed with tyrosinase solution (40 $\mu \mathrm{L})$ and phosphate buffer $(100 \mu \mathrm{L}, \mathrm{pH} 6.8)$ in a 96-well microplate and incubated for $15 \mathrm{~min}$ at $25^{\circ} \mathrm{C}$. The reaction was then initiated with the addition of L-DOPA $(40 \mu \mathrm{L})$. Similarly, a blank was prepared by adding sample solution to all reaction reagents without enzyme (tyrosinase) solution. The sample and blank absorbances were read at $492 \mathrm{~nm}$ after a 10 min incubation at $25{ }^{\circ} \mathrm{C}$. The absorbance of the blank was subtracted from that of the sample and the tyrosinase inhibitory activity was expressed as equivalents of kojic acid.

\section{a-amylase inhibition}

$\alpha$-amylase inhibitory activity was performed using CarawaySomogyi iodine/potassium iodide (IKI) method (24) with some modifications. Sample solution $(25 \mu \mathrm{L})$ was mixed with $\alpha$-amylase solution $(50 \mu \mathrm{L})$ in phosphate buffer $(\mathrm{pH}$ 6.9 with $6 \mathrm{mM}$ sodium chloride) in a 96-well microplate and incubated for $10 \mathrm{~min}$ at $37{ }^{\circ} \mathrm{C}$. After pre-incubation, the reaction was initiated with the addition of starch solution $(50 \mu \mathrm{L}, 0.05 \%)$. Similarly, a blank was prepared by adding sample solution to all reaction reagents without enzyme ( $\alpha$-amylase) solution. The reaction mixture was incubated $10 \mathrm{~min}$ at $37^{\circ} \mathrm{C}$. The reaction was then stopped with the addition of $\mathrm{HCl}(25 \mu \mathrm{L}, 1 \mathrm{M})$. This was followed by addition of the iodine-potassium iodide solution $(100 \mu \mathrm{L})$. The sample and blank absorbances were read at $630 \mathrm{~nm}$. The absorbance of the blank was subtracted from that of the sample and the $\alpha$-amylase inhibitory activity was expressed as equivalents of acarbose.

\section{a-glucosidase inhibition}

a-glucosidase inhibitory activity was performed by the previous method (25) with some modifications. Sample solution $(50 \mu \mathrm{L})$ was mixed with glutathione $(50 \mu \mathrm{L})$, a-glucosidase solution $(50 \mu \mathrm{L})$ in phosphate buffer $(\mathrm{pH} 6.8)$ and PNPG $(50 \mu \mathrm{L})$ in a 96-well microplate and incubated for $15 \mathrm{~min}$ at $37^{\circ} \mathrm{C}$. Similarly, a blank was prepared by adding sample solution to all reaction reagents without enzyme (a-glucosidase) solution. The reaction was then stopped with the addition of sodium carbonate $(50 \mu \mathrm{L}, 0.2 \mathrm{M})$. The sample and blank absorbances were read at $400 \mathrm{~nm}$. The absorbance of the blank was subtracted from that of the sample and the a-glucosidase inhibitory activity was expressed as equivalents of acarbose.

\section{Fatty acid analysis}

The oil extraction of dried and powdered plant parts (10 g) was carried out at boiling point for $6 \mathrm{~h}$ using a Soxhlet extractor and petroleum ether as a solvent. The solvent was evaporated by rotary evaporator. The oil was esterified to determine fatty acid composition. The fatty acids in the oil were esterified into methyl esters by saponification with 0.5 
mol/L methanolic $\mathrm{NaOH}$ and transesterified with $14 \% \mathrm{BF} 3$ $(\mathrm{v} / \mathrm{v})$ in methanol (26).

Fatty acid methyl esters (FAMEs) were analyzed on a HP (Hewlett Packard) Agilent 6890N model gas chromatograph (GC), equipped with a flame ionization detector (FID) and fitted to a HP-88 capillary column $(100 \mathrm{~m}, 0.25 \mathrm{~mm}$ i.d. and $0.2 \mu \mathrm{m})$. Injector and detector temperatures were set at 250 and $280^{\circ} \mathrm{C}$, respectively. The oven was programmed at 60 ${ }^{\circ} \mathrm{C}$ initial temperature and $1 \mathrm{~min}$ initial time. Thereafter the temperature was increased up to $190{ }^{\circ} \mathrm{C}$ rate of $20^{\circ} \mathrm{C} /$ $\mathrm{min}^{-1}$ held for $60 \mathrm{~min}$ then increased at $1{ }^{\circ} \mathrm{C} / \mathrm{min}$ to $220^{\circ} \mathrm{C}$ and held for $10 \mathrm{~min}$ at $220^{\circ}$. Total run time was $107.5 \mathrm{~min}$. Helium was used as carrier gas $(1 \mathrm{~mL} / \mathrm{min})$. Identification of fatty acids was carried out by comparing sample FAME peak relative retention times with those obtained for Alltech and Accu standards. Results were expressed as FID response area in relative percentages. Each reported result is given as the average value of three GC analyses.

\section{Statistical analysis}

For all the experiments all the assays were carried out in triplicate. The results are expressed as mean values and standard deviation (SD). The differences between the different extracts were analyzed using one-way analysis of variance (ANOVA) followed by Tukey's honestly significant difference post hoc test with $\alpha=0.05$. This treatment was carried out using SPSS v. 14.0 program.

\section{Results and Discussion}

Total phenolic and flavonoid contents of $M$. autumnalis extracts and fatty acid profile

Secondary metabolites including alkaloids, flavonoids, tannins and saponins are usually generated by plants that serve as defence mechanism (27). Phenolic compounds are one of the most commonly occurring groups of seconder metabolites. Plant phenolic possess important functions including antiallergenic, antimicrobial, antiartherogenic, antithrombotic, antiinflammatory, vasodilatory and cardioprotective effects $(28,29)$. Indeed, polyphenols showed potent antioxidant activity $(30,31)$. For this reason, phenolic compounds have great interest in recent years. The total phenolic contents of $M$. autumnalis extracts ranged from 26.10 to $46.92 \mathrm{mgGAE} / \mathrm{g}$ extract. F-Met extract contained the highest total phenolic contents (46.92 mgGAE/g extract), followed by L-Ac (40.09 $\mathrm{mgGAE} / \mathrm{g}$ extract) and F-Ac (32.12 mgGAE/g extract). The amount of phenolic content in extracts changed according to the plant part and the solvent. In accordance with our previous study, the phenolic content may vary significantly between the different plant parts $(21,32)$. The highest levels of flavonoids were detected in the L-Met and F-Ac (26.11 and $13.08 \mathrm{mgRE} / \mathrm{g}$ extract, respectively) (Table 1 ).

Table 1. Total phenolic and flavonoid content and total antioxidant capacity (by phosphomolybdenum assay) of Mandragora autumnalis.

\begin{tabular}{llll}
\hline $\begin{array}{l}\text { Plants Solvent } \\
\text { parts }\end{array}$ & $\begin{array}{l}\text { Total phenolic } \\
\text { content }\end{array}$ & $\begin{array}{l}\text { Total } \\
\text { flavonoid } \\
\text { content }\end{array}$ & $\begin{array}{l}\text { Phosphomo- } \\
\text { lybdenum }\end{array}$ \\
& $\begin{array}{l}\text { (mgGAE/g }^{\text {extract })^{\mathrm{a}}} \\
\text { (mmolTE/g }^{\text {(mgRE/g }}\end{array}$ & $\begin{array}{l}\text { extract) } \\
\text { extract) }\end{array}$ & \\
\hline
\end{tabular}

Flowers Acetone $\quad 32.12 \pm 0.49^{*} \quad 13.08 \pm 0.70 \quad 1.14 \pm 0.01$

Methanol $46.92 \pm 0.96 \quad 4.09 \pm 0.10 \quad 1.20 \pm 0.05$

Leaves Acetone $\quad 40.09 \pm 0.56 \quad 3.60 \pm 0.25 \quad 1.98 \pm 0.01$

Methanol $26.10 \pm 0.36 \quad 26.11 \pm 0.09 \quad 1.03 \pm 0.03$

${ }^{a}$ GAEs. gallic acid equivalents

${ }^{\mathrm{b}} \mathrm{REs}$. rutin equivalents

c TEs. trolox equivalents

*Values expressed are means \pm SD

Clinical and epidemiologic studies have shown that many chronic diseases are related to fatty acid type (33). Also, some fatty acids also exhibited very important biological activities such as anti-diabetic, anti-bacterial and anti-inflammatory (34). Again, plant oils could considered as healthy oils due to high concentrations of polyunsaturated fatty acids. In this sense, we investigated the fatty acid compositions of the flowers and leaves of $M$. autumnalis. The results are listed in Table 2 . The most predominant fatty acids were $\alpha$-linoleic acid (C18:3 $\omega 3$ ), linoleic acid (C18:2 $\omega 6)$, palmitic acid (C16:0). Polyunsaturated fatty acids (PUFAs) were the major group of the fatty acids in flowers and leaves. Similar results were reported by our previous study $(26,35)$. According to Table 2 , there no important differences in the two parts (flowers and leaves) for the fatty acid composition. The results indicated that the $M$. autumnalis can be considered as a source of essential fatty acids ( $\alpha$-linoleic acid and linoleic acid). 
Table 2. Fatty acid composition of $M$. autumnalis (flowers and leaves).

\begin{tabular}{|c|c|c|}
\hline & Flowers & Leaves \\
\hline C 8:0 & $0.03 \pm 0.01^{\mathrm{a}}$ & $0.02 \pm 0.00$ \\
\hline C 10:0 & $0.03 \pm 0.01$ & $0.04 \pm 0.01$ \\
\hline C 12:0 & $0.06 \pm 0.01$ & $1.33 \pm 0.64$ \\
\hline C 13:0 & $0.03 \pm 0.01$ & $2.98 \pm 0.06$ \\
\hline C 14:0 & $0.74 \pm 0.01$ & $1.04 \pm 0.03$ \\
\hline C 15:0 & $0.38 \pm 0.01$ & $0.15 \pm 0.00$ \\
\hline C 16:0 & $27.69 \pm 0.07$ & $21.76 \pm 0.05$ \\
\hline C 17:0 & $0.26 \pm 0.01$ & $0.19 \pm 0.01$ \\
\hline C 18:0 & $4.59 \pm 0.03$ & $4.95 \pm 0.14$ \\
\hline C 20:0 & $0.01 \pm 0.01$ & $0.02 \pm 0.00$ \\
\hline C 21:0 & $0.06 \pm 0.01$ & $0.15 \pm 0.02$ \\
\hline C 22:0 & $0.01 \pm 0.01$ & $0.02 \pm 0.01$ \\
\hline$\Sigma \mathrm{SFA}^{\mathrm{b}}$ & $33.88 \pm 0.11$ & $32.62 \pm 0.53$ \\
\hline C $14: 1 \omega 5$ & $0.03 \pm 0.01$ & $0.43 \pm 0.04$ \\
\hline C $15: 1 \omega 5$ & $0.15 \pm 0.01$ & $0.48 \pm 0.09$ \\
\hline C $16: 1 \omega 7$ & $0.17 \pm 0.01$ & $0.22 \pm 0.00$ \\
\hline C $17: 1 \omega 7$ & $0.01 \pm 0.01$ & $0.21 \pm 0.04$ \\
\hline C $18: 1$ n9 & $1.82 \pm 0.01$ & $0.52 \pm 0.01$ \\
\hline C $20: 1 \omega 9$ & $0.09 \pm 0.01$ & $0.20 \pm 0.03$ \\
\hline$\Sigma$ MUFA $^{\text {b }}$ & $2.25 \pm 0.02$ & $2.05 \pm 0.03$ \\
\hline C 18:2 $\omega 6$ & $27.10 \pm 0.04$ & $23.14 \pm 0.10$ \\
\hline C $18: 3 n 6$ & $1.95 \pm 0.12$ & $1.53 \pm 0.25$ \\
\hline C $18: 3 n 3$ & $33.81 \pm 0.03$ & $39.15 \pm 0.17$ \\
\hline C $20: 2 \omega 6$ & $1.00 \pm 0.04$ & $1.48 \pm 0.02$ \\
\hline$\Sigma$ PUFA $^{\mathrm{b}}$ & $63.85 \pm 0.23$ & $65.30 \pm 0.54$ \\
\hline$\Sigma \mathbf{U F A}^{\mathrm{b}}$ & $66.10 \pm 0.25$ & $67.35 \pm 0.57$ \\
\hline EFA $^{b}$ & $60.91 \pm 0.06$ & $62.29 \pm 0.27$ \\
\hline
\end{tabular}

${ }^{a}$ Values reported are means \pm S.D. ${ }^{\mathrm{b}}$ SFA: Saturated fatty acids, MUFA: Monounsaturated fatty acids, PUFA: Polyunsaturated fatty acids, UFA:Unsaturated fatty acids, EFA: Essential fatty acids

\section{Antioxidant activity}

Total antioxidant capacity was evaluated by phosphomolybdenum method. The method is based on the reduction of Mo (VI) to Mo (V) by antioxidants and subsequent formation of green phosphate/Mo (V) complex at acidic $\mathrm{pH}$ (about 2). In phosphomolybdenum assay, total antioxidant capacity did not vary greatly between extracts, and the values ranged from 1.03 to $1.98 \mathrm{mmolTE} / \mathrm{g}$ extract. Total antioxidant capacity of the extracts was higher in L-Ac [1.98 mmolTE/g extract] followed by F-Met [1.20 mmolTE/g extract $]>$ F-Ac $[1.14 \mathrm{mmolTE} / \mathrm{g}$ extract $]$ and L-Met [1.03 $\mathrm{mmolTE} / \mathrm{g}$ extract]. Total antioxidant capacity of the extracts may be due to bioactive compounds [such as phenolic and flavonoids]. Our result confirmed previous finding of Nagulsamy et al., (36).

Free radical scavenging activity of extracts were evaluated by DPPH assay. The DPPH method has been widely used to determine antioxidant activity because of it is an easy, rapid, and stable (37). F-Met has the strongest free radical scavenging activity with $73.09 \mathrm{mg} \mathrm{TE} / \mathrm{g}$ extract compared to the other extracts, while L-Ac the weakest activity. F-Met containing the highest amount of phenolic content exhibited the strongest DPPH radical scavenging activity. The phenolic content may be attributed to DPPH radical scavenging activity of F-Met. As for Metal chelating activity, the highest chelating activity was found in F-Met [15.94 mgEDTA/g extract], followed by F-Ac [15.61 mgEDTA/g extract] > L-Met [11.64 mgEDTA/g extract] > L-Ac [6.15 mgEDTA/g extract]. The metal chelating activities of the extracts varied according to the plant parts as well as the solvent used.

Reducing abilities of plants may serve as an important indicator of its antioxidant activity. Reducing abilities were assessed by FRAP and CUPRAC assays. FRAP and CUPRAC assays have been widely used to determine the antioxidant activity of plants. The FRAP values of extracts varied significantly (50.41 to $90.88 \mathrm{mg} \mathrm{TE} / \mathrm{g}$ extract). The FRAP values of extracts decreased in the order of F- Met $[90.88$ $\mathrm{mgTE} / \mathrm{g}$ extract $]>\mathrm{L}-\mathrm{Ac}[53.53 \mathrm{mgTE} / \mathrm{g}$ extract $]>\mathrm{L}-\mathrm{Met}$ [53.29 mgTE/g extract] > F-Ac [50.41 mgTE/g extract]. Similar results for CUPRAC are reported in present study (Table 3). F-Met [113.24 mgTE/g extract] had the highest CUPRAC value, followed by L-Ac [86.55 $\mathrm{mgTE} / \mathrm{g}$ extract] $>$ L-Met $[77.98 \mathrm{mgTE} / \mathrm{g}$ extract] > F-Ac $[77.47 \mathrm{mgTE} / \mathrm{g}$ extract]. Our results showed that reducing power activity of F-Met may dependent on total phenolic content. These results are accordance with the report earlier published in literature (38). 
Table 3. Free radical (DPPH) scavenging activity, reducing power (FRAP and CUPRAC) and metal chelating activity of Mandragora autumnalis.

\begin{tabular}{|c|c|c|c|c|c|}
\hline Plants parts & Solvent & $\begin{array}{l}\text { DPPH } \\
\text { (mgTE/g extract) }^{a}\end{array}$ & $\begin{array}{l}\text { FRAP } \\
\text { (mgTE/g extract) }^{a}\end{array}$ & $\begin{array}{l}\text { CUPRAC } \\
\text { (mgTE/g extract) }^{a}\end{array}$ & $\begin{array}{l}\text { Metal chelating activity } \\
\text { (mgEDTA/g extract) }\end{array}$ \\
\hline \multirow[t]{2}{*}{ Flowers } & Acetone & $39.30 \pm 0.10^{*}$ & $50.41 \pm 0.16$ & $77.47 \pm 0.48$ & $15.61 \pm 0.08$ \\
\hline & Methanol & $73.09 \pm 0.08$ & $90.88 \pm 2.06$ & $113.24 \pm 1.89$ & $15.94 \pm 0.78$ \\
\hline \multirow[t]{2}{*}{ Leaves } & Acetone & $33.19 \pm 0.13$ & $53.53 \pm 0.86$ & $86.55 \pm 0.90$ & $6.15 \pm 0.24$ \\
\hline & Methanol & $51.44 \pm 0.29$ & $53.29 \pm 0.26$ & $77.98 \pm 0.76$ & $11.64 \pm 1.10$ \\
\hline
\end{tabular}

TEs. trolox equivalents

${ }^{b}$ EDTAEs. disodium edetate equivalents

*Values expressed are means \pm SD

\section{Enzyme inhibitory activity}

Plants and their products open a new era for prevention or treatment common disease in worldwide. Thus, enzyme inhibitory activities of $M$. autumnalis were assessed against the enzymes linked to diabetes, Alzheimer's and skin diseases. The cholinesterase inhibitory activities of M. autumnalis were tested against $\mathrm{AChE}$ and $\mathrm{BChE}$ enzymes, which are connected to Alzheimer's disease. The F-Met extract was the most potent activity for AChE, while L-Ac exhibited remarkable inhibitory activity on $\mathrm{BChE}$. The flowers and leaves of M. autumnalis were evaluated to determine their effect on $\alpha$-amylase and $\alpha$-glucosidase. $\alpha$-amylase inhibitory activity of extracts decreased in the order of L-Ac [1.86 mmolACAE/g extract $]>$ F-Ac [1.27 mmolACAE/g extract] $>$ L-Met $[0.51$ mmolACAE/g extract $]>$ F-Met $[0.46$ mmolACAE/g extract]. For $\alpha$-amylase, acetone extract had stronger activity than methanol extract. In constrat to a-amylase assay, L-Ac extract showed no inhibitory activity of $\alpha$-glucosidase. Inhibitory activities of all extracts against $\alpha$-amylase were found to be more potent than $\alpha$-glucosidase. The tyrosinase inhibitory activities of the M. autumnalis are shown in Fig 1 . The highest tyrosinase inhibitory activity was L-Ac [29.68 mgKAE/g extract]. F-Met exhibited no inhibitory activity aganist tyrosinase. The inhibition of tyrosinase activity can be dependent on the hydroxyl group of phenolic compounds in M. autumnalis. These findings are accordance with Prasad et al., (39), Fatiha et al., (40) and Zengin et al., (32). In the literature, no publications were found about the antioxidant and enzyme inhibitory activity of M. autumnalis

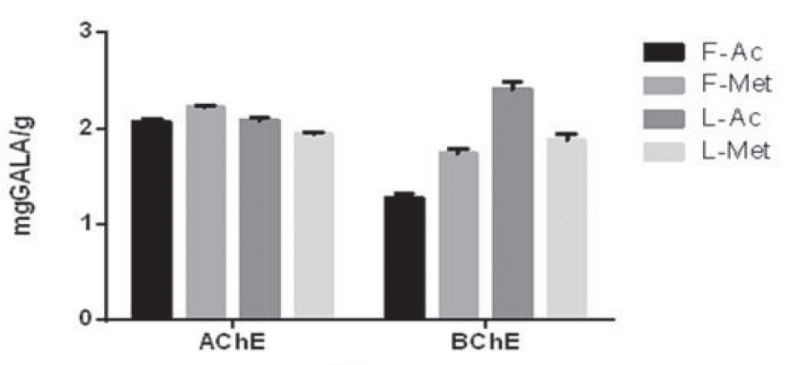

(a)

Figure 1. a. Acetylcholinesterase and Butyrylcholinesterase inhibitory activity (GALAEs, galanthamine equivalets).

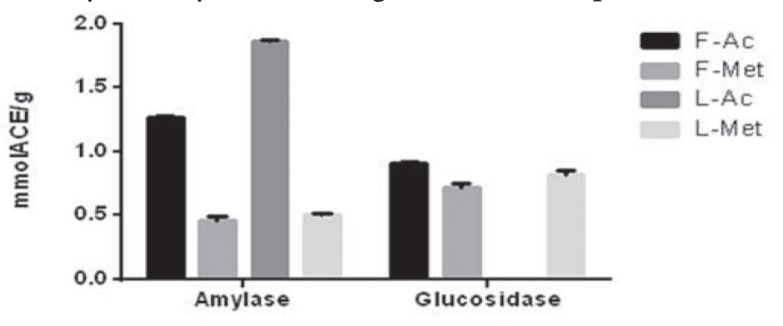

(b)

Figure 1. b. $\alpha$-amylase and $\alpha$-glucosidase inhibitory activity (ACEs, acarbose equivalents).

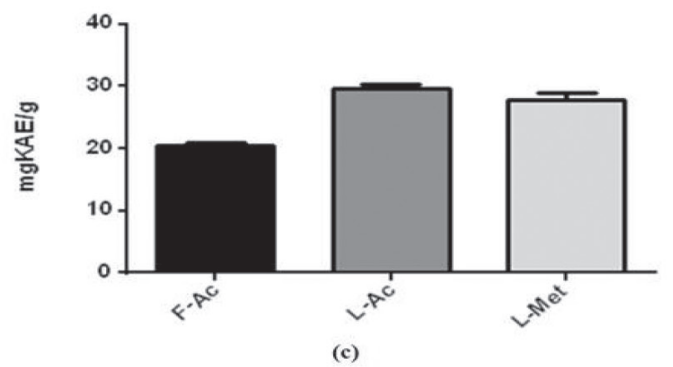

Figure 1. c. Tyrosinase inhibitory activity (KAEs, kojic acid equivalents). 


\section{Conclusion}

The present study carried out in order to evaluate to antioxidant and enzyme inhibitory activity of flowers and leaves extracts of $M$. autumnalis. In the present study, the values of antioxidant and enzyme inhibitory activity vary among the different solvent and plant parts. Generally, F-Met showed the strongest antioxidant activity with the higher concentration of phenolics. M. autumnalis extract indicated remarkable inhibitory effects on cholinesterase, tyrosinase, amylase and glucosidase. Moreover, the oils obtained from flowers and leaves of $M$. autumnalis contained the higher concentrations of polyunsaturated fatty acids. Taken together, the results suggested that $M$. autumnalis could be considered as a source of natural agents in food and pharmaceutical applications.
Mandragora autumnalis özütlerinin enzim inhibitor etkileri ve antioksidan özellikleri ile yağ asidi komposizyonu

\section{ÖZ}

Mevcut araştırma, Mandragora autumnalis'in iki farkl kısmından (çiçek ve yaprak) elde edilen iki özütün (aseton ve metanol) antioksidan aktivitesini ve enzim inhibitör potansiyelini değerlendirmek için gerçekleştirdi. Antioksidan özellikler farklı metotlar kullanılarak değerlendirildi. Enzim inhibitör potansiyelleri kolinesteraz [AChE ve BChE], tirozinaz, $\alpha$-amilaz ve $a$-glukozidaz enzimlerine karşı test edildi. Yağ asitleri, total fenolik ve flavonoid içerik fitokimyasal bileşim için araştırıldı. Genellikle, çiçek metanol özütü (F-Met) yüksek seviyede fenolik ile güçlü antioksidan etki sergiledi. Total fenolik ve flavonoid içerik sırasıyla 26.10-46.92 mgGAE/g özüt ve 3.60-26.11 mgRE/g özüt olarak belirlenmiştir. $\alpha$ - linolenik asit çalışılan yağlarda [çiçek için \%33.81 ve yaprak için \%39.15) major yağ asidi olarak bulundu. Bu çalışma Mandragora autumnalis bitkisinin gida ve ilaç uygulamalarında doğal ajan olarak değerli olabileceğini önermektedir.

Anahtar kelimeler: Antioksidan aktivite, enzim inhibitör aktivite, Mandragora autumnalis, fenolik bileşikler.

\section{REFERENCES}

1. Novak J, Bitsch C, Langbehn J, Pank F, Skoula M, Gotsiou Y. Ratios Of cis-trans-sabinene hydrate in Origanum majorana L. and Origanum microphyllum. Biochem Syst Ecol 2000; 28: 697-704.

2. Türkiye Bitkileri Listesi (Damarlı Bitkiler). Editörler: Güner A, Aslan S, Ekim T, Vural M, Babac MT. Nezahat Gökyiğit Botanik Bahçesi ve Flora Araştırma Derneği Yayını. İstanbul. 2012.

3. Baytop T. Türkçe Bitki Adları Sözlüğü. Türk Dil Kurumu Yayınları. 2007.

4. Ramoutsaki IA, Dimitriou H, Kalmanti M. Management of childhood diseases in the Byzantine period: I-Analgesia. Pediatrics Int 2002; 44: 335-7.

5. Chidiac EJ, Romeo MD, Kaddoum MD, Samir F, Fuleihan MD. Mandragora: Anesthetic of the Ancients. Anesth Analg 2012; 115: 1437-41.

6. Zohary M. Plants of the Bible. Cambridge University Press, Cambridge. 1982.

7. Bekkouche K, Lazrek HB, Jana M. Plant. Med Phytother 1993; 26: 309 .

8. Nutton V. The rise of medicine. In: Cambridge Illustrated History of Medicine, Cambridge Editor: Porter R, Univ Press. Cambridge. 1996, pp 52-81.

9. Von Hintzenstern U. Anaesthesia with mandrake in the tradition of Dioskorides and its role in classical antiquity. In: The History of Anaesthesia, Royal Society of Medicine
International Congress and Symposium Series. Editors: Atkinson RS, Boulton TB. The Parthenon Publishing Group. London 1989, pp 134: 38-40.

10. Al-Khalil S, Alkofahi A. The chemical constituents of Mandragora autumnalis. Alex J Pharm Sci 1996; 10: 135-8.

11. Alzheimer's Disease International, World Alzheimer Report 2009; 1-24.

12. International Diabetes Federation. IDF Diabetes Atlas Seventh edition. Available in: http://www.diabetesatlas.org/ [Accessed: 28.03.2016].

13. Etxeberria U, de la Garza AL, Campio'n J, Martı'nez JA, Milagro FI. Antidiabetic effects of natural plant extract via inhibition of carbohydrate hydrolysis enzymes with emphasis on pancreatic alpha amylase. Expert Opin Ther Targets 2012; 16: 269-97.

14. Murraya AP, Faraonia MB, Castroa MJ, Alzaa NP, Cavallaro V. Natural AChE Inhibitors from Plants and their Contribution to Alzheimer's Disease Therapy. Curr Neuropharmacol 2013; 11: 388-413.

15. Slinkard K, Singleton VL. Total phenol analyses: Automation and comparison with manual methods. Am J Enol Vitic 1977; 28: 49-55.

16. Arvouet-Grand A, Vennat B, Pourrat A, Legret P. Standardization of a propolis extract and identification of the main constituents. J Pharm de Belg 1994; 49: 462-8.

17. Sarikurkcu C. Antioxidant activities of solvent extracts from endemic Cyclamen mirabile Hildebr. tubers and leaves. Afr J Biotechnol 2001; 10: 831-9. 
18. Berk S, Tepe B, Arslan S, Sarikurkcu C. Screening of the antioxidant, antimicrobial and DNA damage protection potentials of the aqueous extract of Asplenium ceterach D.C. Afr J Biotechnol 2011; 10: 8902-8.

19. Apak R, Guclu K, Ozyurek M, Karademir SE, Ercag E. The cupric ion reducing antioxidant capacity and polyphenolic content of some herbal teas. Int J Food Sci Nutr 2006; 57: 292304.

20. Aktumsek A, Zengin G, Guler GO, Cakmak YS, Duran A. Antioxidant potentials and antisholinesterase activities of methanolic and aqueous extracts of three endemic Centaurea L. species. Food Chem Toxicol 2013; 55: 290-6.

21. Zengin G, Aktumsek A. Investigation of antioxidant potentials of solvent extracts from different anatomical parts of Asphodeline anatolica E. Tuzlaci: an endemic plant to Turkey. Afr J Tradit Complem 2014; 11: 481-88.

22. Ellman GL, Courtney KD, Andres V, Featherstone RM. A new and rapid colorimetric determination of acetylcholinesterase activity. Biochem Pharmacol 1961; 7: 88-90.

23. Orhan IE, Senol FS, Gulpinar AR, Sekeroglu N, Kartal M, Sener B. Neuroprotective potential of some terebinth coffee brands and the unprocessed fruits of Pistica terebinthus L: and their fatty and essential oil analyses. Food Chem 2012; 130: 882-88.

24. Yang XW, Huang MZ, Jin YS, Sun LN, Song Y, Chen HS. Phenolics from Bidens bipinnata and their amylase inhibitory properties. Fitoterapia 2012; 83: 1169-75.

25. Palanisamy UD, Ling LT, Manaharan T, Appleton D. Rapid isolation of geraniin from Nephelium lappaceum rind waste and its anti-hyperglycemic activity. Food Chem 2011; 127: 217.

26. Aktumsek A, Zengin G, Guler GO, Cakmak YS, Duran A. Assessment of the antioxidant potential and fatty acid compositionof four Centaurea L. taxa from Turkey. Food Chem 2013; 141: 91-7.

27. Kliebenstein DJ. Secondary metabolites and plant/ environmentinteractions: A view through Arabidopsis thaliana tinged glasses. Plant Cell Environ 2004; 27: 675-84.

28. Middleton E, Kandaswami C, Theoharides TC: The effects of plantflavonoids on mammalian cells: Implications for inflammation, heart disease and cancer. Pharmacol Rev 2000; 52: 673-751.

29. Alpınar K, Ozyurek M, Kolak U, Guclu K, Aras C, Altun M, Celik SE, Berker KI, Bektasoglu B, Apak R. Antioxidant
Capacities of Some Food Plants Wildly Grown in Ayvalik of Turkey. Food Sci Tech Res 2009; 15: 59-64.

30. Bors W, Werner H, Michel C, Saran M. Flavonoids as antioxidants: Determination of radical-scavenging efficiencies. Methods Enzymol 1990; 186: 343-55.

31. Hanasaki Y, Ogawa S, Fukui S. The correlation between active oxygen scavenging and antioxidative effects of flavonoids. Free Radic Biol Med 1994; 16: 845-50.

32. Zengin G, Uysal S, Ceylan R, Aktumsek A. Phenolic constituent, antioxidative and tyrosinase inhibitory activity of Ornithogalum narbonense L. from Turkey: A phytochemical study. Ind Crop Prod 2015; 70: 1-6.

33. WHO Report of a joint FAO/WHO expert consultation: Diet, nutrition and the prevention of chronic diseases, Geneva 2003.

34. Yashodhara BM, Umakanth S, Pappachan JM, Bhat SK, Kamath R, Choo BH. Omega-3 fatty acids: A comprehensive review of their role in health and disease. Postgrad Med J 2009; 85: $84-90$.

35. Uysal S, Zengin G, Aktumsek A, Karatas S. Fatty acid composition, total sugar content and anti-diabetic activity of methanol and water extracts of nine different fruit tree leaves collected from Mediterranean Region of Turkey. Int J Food Prop 2015; 18: 2268-76.

36. Nagulsamy P, Ponnusamy R, Thangaraj P. Evaluation of antioxidant, anti-inflammatory, and antiulcer properties of Vaccinum leschenaultia Wight: A therapeutic supplement. J Food Drug Anal 2005, 23:376-86.

37. Koleva, II, Van Beek JPH, Linseen A, De G, Evstatieva LN. Screening of plant extracts for antioxidant activity: a comparative study on three testing methods. Phytochem Anal 2002; 10: 178-82.

38. Huang D, Ou B, Prior RL. The chemistry behind antioxidant capacity assays. J Agric Food Chem 2005; 53: 1841-56.

39. Prasad KN, Yang B, Shi J, Yu C, Zhao M, Xue S, Jiang Y. Enhanced antioxidant and antityrosinase activities of longan fruit pericarp by ultra-high-pressure-assisted extraction. J Pharm Biomed Anal 2010; 51: 471-7.

40. Fatiha B, Didier H, Naima G, Khodir M, Martin K, Léocadie K, Caroline S, Mohamed C, Pierre D. Phenolic composition, in vitro antioxidant effects and tyrosinase inhibitory activity of three Algerian Mentha species: M. spicata (L.), M. pulegium (L.) and M. rotundifolia (L.) Huds (Lamiaceae). Ind Crop Prod 2015; 74: 722-30. 